\title{
Perceraian dalam Persepsi Psikologi Komunikasi di Kota Bandung serta Penganggulangannya
}

\author{
Lia Kurniawati ${ }^{1}$, Milla Mustikawati ${ }^{2}$ \\ ${ }^{1,2}$ Politeknik Kridatama \\ Email: ${ }^{1}$ liakurniawati@politeknik-kridatama.ac.id, ${ }^{2}$ millamustikawati@politeknik-kridatama.ac.id
}

\begin{abstract}
Abstact. Personal Factors in Divorce Figures in Psychological Studies Communication is essentially a shared responsibility between family and government officials as social control. In order to support the empowerment of reducing divorce rates in several sub-districts in Bandung, the strategies carried out in this study include first optimizing the role of academic consultants in assisting PKK cadres and young people who will enter the marriage level (final level students). Second, socializing self-empowerment in the two targets above, third Increasing the participation of government institutions such as academics (the field of communication psychology), District KUA and Disdukcapil. During the research period, ther rate of divorce in Bandung the above strategies can reduce it. But it can't be expected that implementing in adapting to empowering and recognizing their potential. The ultimate goal of this study as a basic material to improve the quality of Human Resources, especially every person who will enter the marriage level can prepared their perception about relationship and how to manage communication with their couple or families also in economics problems. A major change in an individual personally has an impact on social, cultural and especially economic changes. The fact that the divorce rate according to statistical data from several disdukcapil institutions and the Office of Religious Affairs turns out that the role of personality problems is divided into several parts, including the most dominating economic factors. While the method that will be used in achieving this goal is to provide guidance in the form of a seminar on self-management, a workshop to become a qualified person in accordance with the achievement of material and immaterial targets with the target of each individual aged 20-40 years. The results showed that the people of Bandung city from several sub-districts with the optimization of the role of academics and the role of KUA and disukcapil get a psychological approach so as to reduce divorce rates in the city of Bandung.
\end{abstract}

Keywords: communication, divorce, communication strategy, interpersonal communication strategy, communication psychology.

\begin{abstract}
Abstrak. Faktor Personal Angka Perceraian dalam Kajian Psikologi Komunikasi pada hakekatnya merupakan tanggung jawab bersama antara keluarga dan pihak-pihak pemerintah sebagai kontrol sosial kemasyarakatan. Dalam rangka mendukung pemberdayaan pengurangan angka perceraian di beberapa kecamatan di Kota Bandung, strategi yang dilakukan dalam penelitian ini antara lain adalah pertama mengoptimalkan peran konsultan akademik dalam melakukan pendampingan para kader PKK dan pemuda pemudi yang akan memasuki jenjang pernikahan (Mahasiswa tingkat akhir). Kedua, mensosialisasikan pemberdayaan diri pada kedua target di atas, ketiga Meningkatkan peran serta lembaga pemerintah seperti akademisi (bidang psikologi komunikasi), KUA Kecamatan dan Disdukcapil. Diharapkan dengan melaksanakan strategi-strategi diatas dapat mengurangi tingkat angka perceraian di kota Bandung selama kurun waktu penelitian dan tidak lagi mengalami kesulitan dalam beradaptasi dalam memberdayakan dan mengenali potensi diri. Tujuan akhir dari penelitian ini sebagai bahan dasar untuk meningkatkan kualitas Sumber Daya Manusia terutama setiap pribadi yang akan memasuki jenjang pernikahan sehingga berimbas pada efek kebahagiaan dan hidup yang berkualitas dari satu keluarga inti. Perubahan besar seorang individu secara personal berdampak pada perubahan sosial, budaya dan terlebih perekonomian. Fakte dilapangan bahwa angka perceraian menurut data statistik dari beberapa institusi disdukcapil dan Kantor Urusan Agama ternyata peran permasalahan kepribadian terbagi menjadi beberapa bagian diantaranya faktor ekonomi yang paling mendominasi. Sedangkan metode yang akan dipakai dalam pencapaian tujuan tersebut adalah memberikan pembinaan berupa seminar manajemen diri, workshop menjadi pribadi berkualitas sesuai dengan capaian target materil dan imateril dengan target sasaran setiap individu berusia 20-40 tahun. Hasil penelitian menunjukkan bahwa masyarakat kota Bandung dari beberapa kecamatan dengan adanya optimalisasi peran akademisi dan peran KUA serta disukcapil mendapatkan pendekatan secara psikologis sehingga dapat mengurangi angka perceraian di Kota Bandung.
\end{abstract}

Kata Kunci : komunikasi, perceraian, strategi komunikasi intrapersonal, strategi komunikasi interpersonal, psikologi komunikasi. 


\section{A. PENDAHULUAN}

Meningkatnya angka perceraian pada keluarga muda dengan anggota keluarga 1-2 orang keturunan menjadi sorotan yang menarik terlebih angka perceraian ini peneliti amati terjadi pada rentang usia 30-40 tahunan di Kota Bandung. Berdasarkan data yang ada di Pengadilan Tinggi Agama di Kota Bandung, tercatat 415 kasus gugatan perceraian tahun 2017. Sebuah fenomena menarik untuk diteliti. Menurut Ahmad Mujahidin, Panitera muda ; "Jumlah/angka tersebut terdiri dari gugat cerai pihak perempuan sebanyak 4. 113 gugatan sedangkan cerai talak dari pihak laki-laki sebanyak 1. 302 gugatan (wawancara 06/02/2018). Data diatas menunjukan bahwa gugat cerai pihak perempuan lebih tinggi, yaitu 75,9\% dibandingkan pihak laki-laki sebanyak 1\%. Jenis perkara perceraian berada pada peringkat pertama 90\% diikuti oleh perkara ijin poligami dan isbath nikah.

Selanjutnya Ahmad Mujahidin menyatakan bahwa terjadinya peningkatan angka perceraian setiap tahunnya sebanyak $5 \%$. Angka perceraiannya pun jika dilihat dari sisi demografis menempati angka tertinggi dibandingkan Kota lain.

Mayoritas penyebab terjadinya perceraian karena faktor ekonomi. Di samping itu tingkat kedewasaan berpikir merupakan salah satu faktor pentingnya pembentukan komunikasi di dalam keluarga. Dari hal tersebut penelitian ini dititikberatkan pada faktor personal dan faktor situasional dalam Psikologi Komunikasi pada angka perceraian di Kota Bandung. Penelitian ini dilaksanakan di Kota Bandung Jawa Barat.

Metode yang digunakan dalam penelitian ini adalah metode kualitatif.
Metode penelitian kualitatif adalah metode penelitian yang digunakan untuk meneliti pada kondisi objek alamiah, dimana peneliti adalah sebagai instrumen kunci, pengambilan sampel sumber data dilakukan secara purposif dan sampai data akhir, teknik pengumpulan dengan gabungan dan analisis data bersifat induktif/kualitatif dan hasil penelitian kualitatif lebih menekankan makna dari pada generalisasi.

Adapun yang dijadikan subjek penelitian adalah kader PKK dan Mahasiswa di beberapa Kecamatan di Kota Bandung Tahun 2018. Dalam penyusunan penelitian ini, penulis melakukan pengumpulan data yang dilakukan untuk memperoleh keterangan serta menganalisis data sehingga data tersebut dapat memberikan informasi untuk penelitian penulis. Menilik jurnal yang telah ada sebagai bahan rujukan dikutip Jurnal Psikologi, Dariyo, 2004 ; "Faktorfaktor penyebab perceraian sebagai sebuah cara yang harus ditempuh oleh pasangan suami-istri ketika ada masalah-masalah dalam huhungan perkawinan mereka tak dapat diselesaikan dengan baik. Perceraian bukanlah tujuan akhir dari suatu perkawinan, akan tetapi sebuah bencana yang melanda mahligai perkawinan antara pasangan suami-istri. Menurut para ahli, seperti Nakamura (1989), Turner \& Helms (1995), Lusiana Sudarto Henny E. Wirawan (2001), ada beberapa faktor penyebab perceraian yaitu a) kekerasan verbal, b) masalah atau kekerasan ekonomi, c) keterlibatan dalam perjudian, d) keterlibatan dalam penyalahgunaan minuman keras, e) perselingkuhan. Namundemikian, mereka tidak memerinci secara jelas faktor-faktor penyebab tersebut". 
Sedangkan Save M. Dagun (1990:114), menyatakan; "banyak faktor yang menyebabkan terjadinya kasus pertikaian dalam keluarga yang berakhir dengan perceraian. Faktor-faktor ini antara lain persoalan ekonomi (2) perbedaan usia yang besar (3) keinginan memperoleh anak (4) persoalan prinsip hidup yang berbeda. Faktor lainnya berupa perbedaan penekanan dan cara mendidik anak, pengaruh dukungan sosial dari pihak luar. Faktor- faktor ini menimbulkan suasana keruh dan meruntuhkan kehidupan rumah tangga yang berakibat pada keretakan keluarga dan perceraian dalam keluarga".

Pendapat Prianto, 2013 dikutip dari Jurnal Unnes, mengutarakan sebagai berikut ;

"Tingkat pendidikan perempuan atau laki-laki yang melakukan perceraian yang menjadi informan penelitian sangat beragam mulai dari tingkat Sekolah Menengah Pertama (SMP) sampai dengan tingkat Sarjana Strata 2 (S2). Sedangkan usia pernikahan yang telah dijalani oleh para informan penelitian berada pada rentang 2 - 25 tahun. Fenomena ini menunjukkan bahwa tingkat pendidikan dan usia perkawinan tidak sepenuhnya dapat menjamin langgengnya hubungan suami isteri untuk tetap menjaga dan membina keutuhan ikatan perkawinan."

Selanjutnya guna mengurangi angka perceraian landasan konsep teoritis mengenai faktor-faktor personal pada persepsi interpersonal menurut Jalaluddin

$$
\text { Rakhmat dalam bukunya }
$$

Psikologi Komunikasi, 2011. Menyatakan, pada tingkat persepsi tinggat kecakapan dalam tanggapan stimulus akan meningkatkan kemampuan persepsi peribadi terhadap pasangan. Persepsi interpesonal besar pengaruhnya pada hubungan interpersonal oleh karena itu kecermatan persepsi interpersonal akan sangat berguna untuk meningkatkan kualitas komunikasi interpersonal kita.
Menurut David A Kenny, teori mengenai persepsi interpersonal "The Idea of Interpersonal perception means the process of making meaning from things we experience to the people" selain itu beberapa faktor-faktor pengaruh personal pada persepsi interpersonal yaitu :

1. Pengalaman, memengaruhi kecermatan persepsi. Pengalaman tiak selalau lewat proses belajar formal. Pengalaman bertambah juga melalui rangkaian peristiwa yang pernah dihadapi. Ini juga sebabnya mengapa kitalebih sukar berdusta di depan orang yang paling dekat dengan kita terutama pasangan, hubungan ibu anak dan keluarga dekat.

2. Motivasi, adalah proses yang menjelaskan intensitas, arah, dan ketekunan seorang individu untuk mencapai tujuannya. Tiga elemen utama dalam definisi ini diantaranya adalah intensitas, arah, dan ketekunan. Sesuai dengan Dalil Komunikasi "Anda hanya mendengar apa yang mau anda dengar, dan anda tidak akan mendengar apa yang ingin anda dengar". Intensitas persepsi yang secara terus menerus dilakukan terhadap pasangan bukan tidak mungkin akan membentuk satu opini tersendiri jika tidak dikomunikasikan dengan baik. Dan itu akan mempersempit ruang persepsi seseorang terhadap orang lain.

3. Kepribadian, dalam psikoanalisis dikenal dengan yang namanya proyeksi, sebagai salah satu cara pertahanan ego. Proyeksi adalah mengeksternalisasi pengalaman subjektif secara tidak sadar. Orang akan melemparkan perasaan bersalahnya pada orang lain. Maling teriak maling 
merupakan contoh tipikal dari proyeksi. Pada persepsi interpersonal, orang akan mengenakan pada orang lain sifatsifat yang ada pada dirinya, yang tidak disenanginya. Dan jelas orang yang banyak melakukan proyeksi tidak akan cermat menanggapi persona stimuli. Sebaliknya orang yang menerima dirinya apa adanya, yang tidak dibebani perasaan bersalah, cenderung menafsirkan orang lain lebih cermat, Rakhmat (2011).

Banyaknya faktor penentu keberlangsungan suatu pernikahan bertahan sampai salah satu pasangan meninggal ataupun bertahan samapi akhir hayat dalam kurun waktu 10 tahun terakhir menjadi wacana yang sangat kritis. Hal ini disebabkan oleh banyak faktor seperti faktor situasional ekonomi menjadi salah satu faktor yang paling dominan. Tetapi di balik itu terdapat faktor lain yang menjadi penentu bertahannya suatuhubungan pernikahan terutama di Kota Bandung.

Tingginya angka perceraian di Kota Bandung, menjadi perhatian banyak pihak terutama peneliti mengapa hal tersebut menjadi wacana tingkat provinsi. Mengapa tertinggi di karenakan jumlah penduduk di Jawa Barat pun termasuk terpadat di antar provinsi yang lain, jadi merupakan perhitungan keseimbangan. Karena cakupan penelitiannya terlalu luas untuk itu peneliti membatasi permasalahan di wilayah cakupan Kota Bandung.

Faktor personal dalam setiap individu sangat banyak diantaranya Tingkat pendidikan sangat beragam mulai dari tingkat Sekolah Menengah Pertama (SMP) sampai dengan tingkat Sarjana Strata 2 (S2). Sedangkan usia pernikahan yang telah dijalani oleh para informan penelitian berada pada rentang 20 - 35 tahun. Hal ini bisa dikaitkan dengan tingkat kematangan pemikiran setiap individu.
Faktor ekonomi yang mendominasi angka perceraian ini artinya ditilik dari tingkat kesiapan kemapananan pemikiran setiap individu yang akan menjalani sebuah biduk rumah tangga, dan kesiapan mental mempunyai tanggung jawab terhadap orang lain masih menjadi faktor utama jika di lihat dari sudut pandang psikologi komunikasi. Adapun faktor-faktor lain yang timbul pada dasarnya adalah dari faktor tersebut di atas.

Berdasarkan perumusan masalah yang sudah dikemukakan diatas maka dengan ini peneliti membatasi penelitian dengan faktor personal angka perceraian dalam kajian Psikologi Komunikasi di Kota Bandung.

Tujuan penelitian mengenai angka perceraian dilihat dari sudut pandang psikologi komunikasi adalah sebagai bahan rujukan yang implikatif untuk peneliti-peneliti lainnya Setelah penelitian ini berlangsung dan di publikasikan. Tujuan umum penelitian ini adalah sebagai acuan masyarakat Kota Bandung agar senantiasa mawas diri, mengenal dirinya sendiri untuk mempertahankan pernikahan sehingga angka perceraian di Kota Bandung menurun. Manfaat dari penelitian ini adalah Setiap pasangan mampu menemukenali faktor personal dalam tataran Psikologi Komunikasi. Dapat menerapkan implikasi pengembangan diri sehingga setiap individu yang terikat dalam ikatan pernikahan lebih mengenal diri dan pasangan mampu menemukan solusi ketika dihadapkan pada persoalan setiap individu pasangan. Sehingga pernikahan dapat berlangsung dengan nyaman dan bertahan lama, sehingga angka Perceraian di Kota Bandung dapat ditekan dan diminimalisir.

\section{B. METODE PENELITIAN}

Pengamatan dilakukan untuk melihat langsung semua aspek yang berhubungan dengan faktor personal 
angka perceraian dalam kajian Psikologi Komunikasi di Kota Bandung. Sasarannya adalah mulai letak geografis, sumber daya manusia, dan program kemasyarakatan yang implikatif di Kota Bandung.

1. Wawancara

Wawancara dilakukan dengan berbagai narasumber dari kader PKK, Dinas Penduduk dan Catatan Sipil serta KUA untuk mendapatkan data atau informasi secara langsung serta lebih rinci berkenaan dengan faktor personal angka perceraian dalam kajian Psikologi Komunikasi di Kota Bandung.

\section{Studi Dokumentasi}

Teknik ini digunakan untuk mengumpulkan data atau informasi yang berkenaan dengan faktor personal angka perceraian dalam kajian Psikologi Komunikasi di Kota Bandung, berupa data dari laman website KUA, Data Dari Disdukcapil, data catatan dari Kader PKK.

\section{HASIL PENELITIAN DAN PEMBAHASAN}

\section{Hasil Analisis dan Verifikasi}

Lokasi penelitian bertempat di Kota Bandung dengan mengambil sample beberapa Tim Penggerak PKK, Mahasiswa Tingkat akhir dan Taruna Karya serta pengambilan data dari Disdukcapil (Dinas Penduduk dan Catatan Sipil), dan Pengadilan Agama Tingkat Kota Bandung. Pengadilan Tinggi Agama Kota Bandung mencatat ada 5.415 gugatan perkara perceraian yang terjadi sepanjang tahun 2017. Angka tersebut didominasi oleh cerai gugat dari pihak perempuan dengan jumlah 4.113. Sementara cerai talak dari pihak pria hanya berjumlah 1.302 gugatan. "Tingkat perceraian di Kota Bandung meningkat terus setiap tahunnya walau tidak signifikan," ujar Panitera Muda Gugatan Pengadilan Tinggi Agama Kota Bandung, Ahmad Mujahidin hasil dari wawancara Selasa (6/2/2018). Angka perceraian itu meningkat sekitar 5\% setiap tahunnya.

Catatan tersebut menempatkan perceraian sebagai jenis perkara yang paling banyak masuk ke meja kerja Pengadilan Agama Tinggi Kota Bandung sebesar $90 \%$. Berada di atas perkara izin poligami dan isbath nikah. Ragam alasan melatarbelakangi banyaknya jumlah perceraian yang terjadi. Tercatat, perselisihan yang terjadi antara pasangan suami istri menjadi penyebab utama dari retaknya rumah tangga dengan jumlah 3.440 kasus. Kedua, perceraian terjadi karena adanya ketidakpuasan terhadap keadaan ekonomi keluarga dengan jumlah 1.313 kasus. Kemudian, penyebab meninggalkan salah satu pihak tercatat ada 504 kasus, poligami 112 kasus, kekerasan dalam rumah tangga 39 kasus, serta sisanya karena mabuk dan judi. Di satu sisi, Kota Bandung memang sangat mengkhawatirkan jika melihat dari angka perceraian. Namun di sisi lain, ini baik karena berarti ada kesadaran dari masyarakat untuk mengurus administrasi perceraian. Uniknya, tingkat perceraian mengalami penurunan drastis ketika memasuki bulan suci Ramadan. Tercatat hanya ada 190 gugatan cerai yang dilayangkan saat bulan Ramadan. Padahal, jika dirata-ratakan, setidaknya dalam satu bulan terdapat 451 gugatan cerai atau 15 kasus sehari. Fenomena dari meningkatnya tren perceraian di Kota Bandung cukup memprihatinkan.

Hal ini memicu perasaan tidak bahagia. Tengok saja hasil survei Badan Pusat Statistik tahun 2017 soal indeks kebahagiaan. Survei itu menyimpulkan jika penduduk dengan status perkawinan cerai hidup dinilai sebagai individu yang paling tidak bahagia dengan indeks 67,83 . Justru, penduduk dengan status belum menikah tercatat sebagai individu paling bahagia dengan raihan indeks sebesar 71,53. Disusul oleh penduduk yang telah menikah dengan indeks sebesar 71,09. 


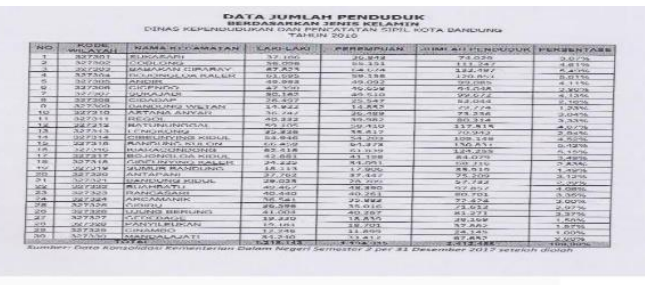

\section{Gambar 1. Data Jumlah Penduduk berdasarkan Status Perkawinan Sumber: Dinas Penduduk dan Catatan Sipil Kota Bandung}

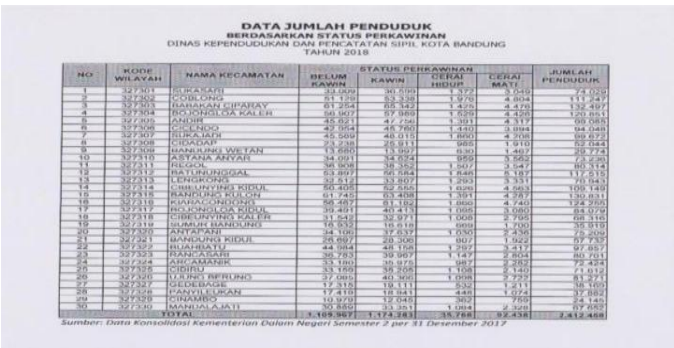

\section{Gambar 2. Data Jumlah Penduduk berdasarkan Jenis Kelamin}

Angka perceraian di Kota Bandung relatif meningkat setiap tahunnya. Berdasarkan hasil wawancara dengan Petugas Pos Bantuan Hukum Pengadilan Agama Bandung Dwi Reiza Meinanti punya catatannya, dari 25 perkara yang dikonsultasikan dan berakhir di persidangan. Rata-rata kasus ini dialami pasangan berumur di atas 30 tahun. Dikarenakan ketidakstabilan dalam kedewaan berpikir. Oleh karena itu dalam perspektif psikologi komunikasi hal ini bisa jadi faktor penyumbang meningkatnya angka perceraian di Kota Bandung beberapa tahun terakhir.

Upaya pelaksana peneliti untuk berkontribusi mengurangi angka perceraian: Penyuluhan faktor motivasi pada tingkat PKK, penyuluhan pada taruna karya memberikan pencerahan dampak-dampak faktor personal dan intrapersonal/interspersonal terhadap keberlangsungan membangun suatu hubungan pada jenjang pernikahan. Selain usia di atas 30 tahun, pasangan berusia di bawah 30 tahun juga menjadi pasangan yang banyak melakukan konsultasi. Perceraian pasangan usia muda kebanyakan karena saat menikah bertujuan menyelamatkan nasib kandungan. Angkanya dalam sehari sekitar 5 dari 25 perkara. Rata-rata usia pernikahan pasangan muda 2-5 tahun. Perceraiannya biasanya dibumbui persoalan karakter yang belum matang. Faktor Penyebab angka Perceraian bersumber Pengadilan Agama Kota Bandung sebagai berikut:

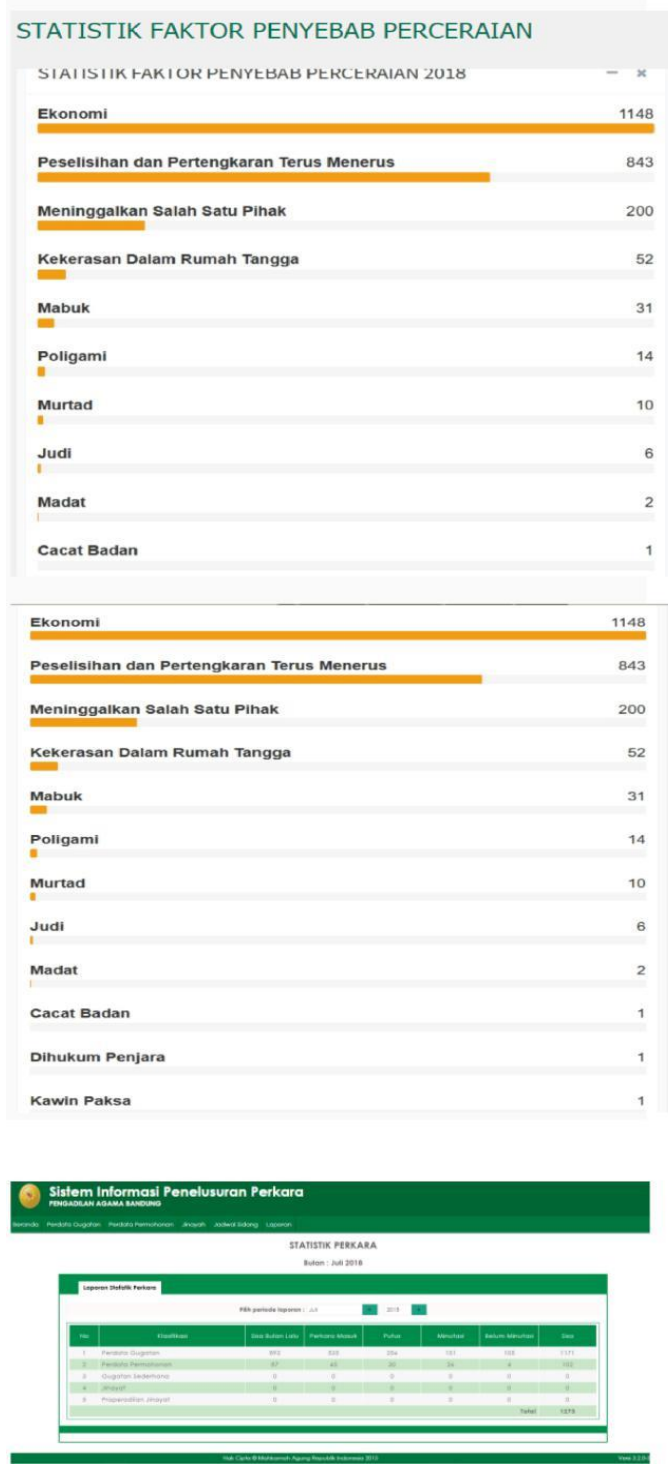

Gambar 3. Faktor Penyebab angka Perceraian bersumber Pengadilan Agama Kota Bandung Sumber : http://sipp.pabandung.go.id/statistik_perkara 


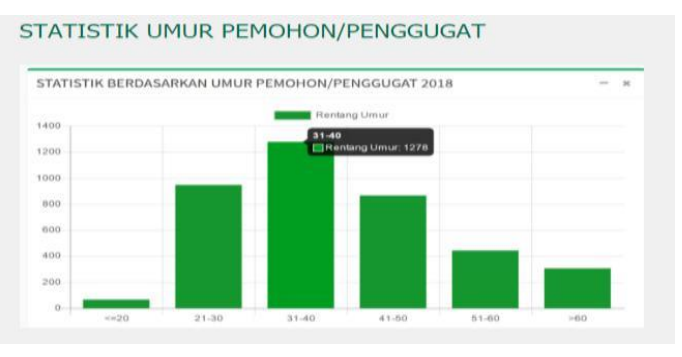

\section{Gambar 4. Data Statistik Angka Perceraian Pengadilan Agama Bandung Berdasarkan Usia}

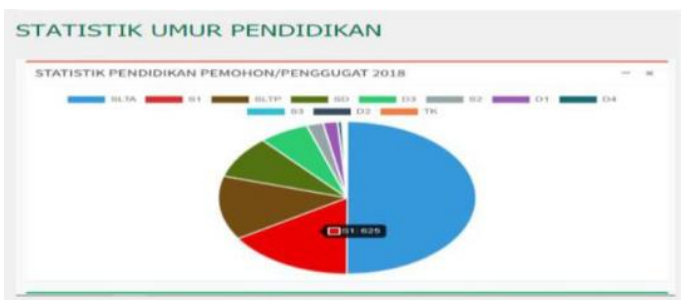

STATISTIK JENIS PERKARA GUGATAN DAN PERMOHONAN
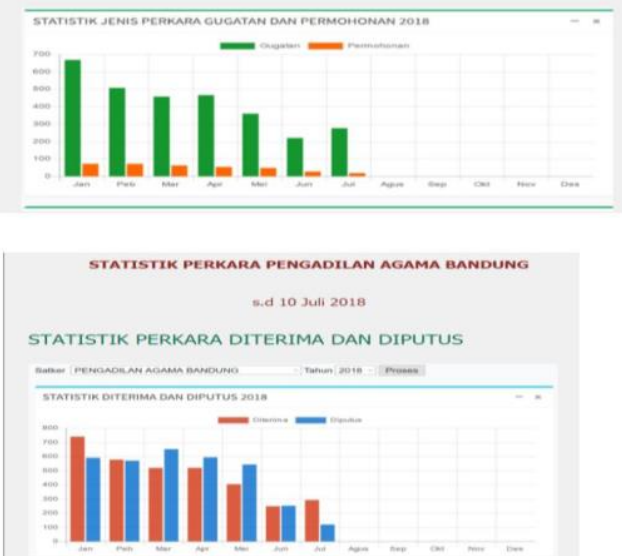

Gambar 5. Data Statistik Angka Perceraian Pengadilan Agama Bandung Berdasarkan Tingkat Pendidikan

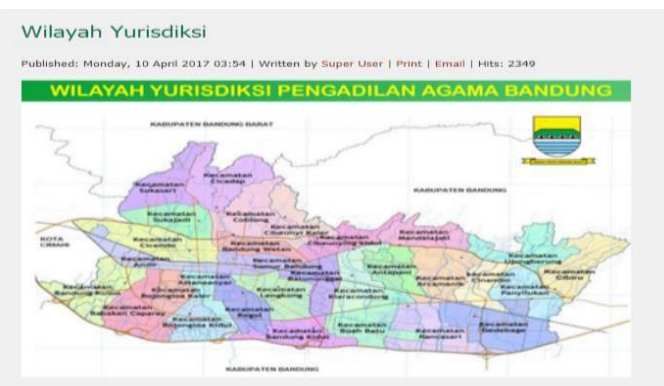

Gambar 6. Data Perceraian Berdasarkan Wilayah cakupan
Pengadilan Agama Bandung merupakan yurisdiksi dari Pengadilan Tinggi Agama Jawa Barat yang terdiri dari 30 Kecamatan dan 151 Kelurahan di Kota Bandung yaitu :

Tantangan bagi kader gerakan Pemberdayaan dan Kesejahteraan Keluarga (PKK) di era modernisasi ini semakin berat. Justru objek penelitian dititikberatkan pada para kader PKK dikarenakan pada usia produktif mereka merupakan penyumbang terbesar angka perceraian. Strategi menyampaikan program pemberdayaan pada faktor personal supaya sesuai dengan kemampuan masyarakat, itu yang menjadi tantangan para akademisi di bidang psikologi komunikasi, pamong pemerintah dalam upaya pembinaan kesejahteraan keluarga guna memberdayakan para pemuda pemudi agar turut merasakan kebahagiaan dalam menjalani kehidupan berumah tangga kelak.

Permasalahan pemberdayaan pemuda dan kader PKK masih dirasakan kurang efektif dikarenakan faktor personal dari kader PKK yang masih membutuhkan pembinaan dari para stake holder pemerintah melalui berbagai pembinaan dan pendampingan. Permasalahan ini dapat diselesaikan jika para akademisi, pamong pemerintah bahu membahu mampu menggandeng organisasi pemuda, TP PKK dan KarangTaruna bekerjasama melakukan pembinaan melalui seminar-seminar dan penyuluhan motivasi dan pemberdayaan diri.

\section{SIMPULAN REKOMENDASI}

\section{Simpulan}

Tantangan bagi kader gerakan Pemberdayaan dan Kesejahteraan Keluarga (PKK) di era modernisasi ini semakin berat. Berbagai rancangan kegiatan masyarakat dalam mensukseskan program pemerintah, memperkecil angka perceraian di Kota 
Bandung harus melibatkan kader PKK serta mengikutsertakan pemuda dalam kegiatan-kegiatan penguatan pemberdayaan faktor personal untuk menghadapi pembentukan dan pemberdayaan diri dalam mensejahterakan kehidupan bersosial yang akan berdampak pada mengecilnya/menurunkan angka perceraian di Kota Bandung.

\section{Rekomendasi}

Pemerintah dalam hal ini (KUA dan Disdukcapil) serta pihak akademik yang peduli terhadap permasalahan sosial saat ini harus lebih responsif terhadap permasalahan di masyarakat, baik yang terkait pemberdayaan diri.

Pemerintah bukan hanya menyelenggarakan kegiatan-kegiatan kelompok kerja, namun mampu menggandeng organisasi pemuda, seperti dan TP PKK, Karang Taruna untuk ikut serta dalam penyuluhan dan edukasi tentang peningkatan dan pengembangan potensi diri. Penulis menilai hal ini cukup sulit, mengingat anak muda masa kini lebih mementingkan urusan ide kreatif daripada kegiatan-kegiatan pemberdayaan diri ke arah pembinaan keluarga.

\section{DAFTAR PUSTAKA}

Baron, R. M., \& Kenny, D. A. (1986). The moderator-mediator variable distinction in social psychological research:

Conceptual, strategic, and statistical

considerations. Journal of

personality and social psychology, 51(6), 1173.

Dagun, S. M. (2002). Psikologi keluarga. Jakarta: Rineka Cipta. Disdukcapil Kota Bandung, 2018 http://sipp.pabandung.go.id/statistik_perkara

Jalaludin, R. (2011). Psikologi komunikasi. Bandung: $\quad P T$ Remaja Rosdakarya.

Mujahidin, A. (2012). Pembaharuan hukum acara peradilan agama: dilengkapi format formulir beperkara. Ghalia Indonesia.

Prianto, B., Wulandari, N. W., \& Rahmawati, A. (2013). Rendahnya komitmen dalam perkawinan sebagai sebab perceraian. Komunitas:

International Journal of Indonesian Society and Culture, 5(2). 